\title{
The effects of advertisements on consumer choices and health: a content analysis of health claims in Italian magazines
}

\author{
Angela Tarabella and Andrea Apicella \\ Department of Economics and Management, University of Pisa, \\ Pisa, Italy, and \\ Sara Tessitore and Maria Francesca Romano \\ Sant'Anna School of Advanced Studies, Institute of Economics, \\ Pisa, Italy
}

\begin{abstract}
Purpose - The purpose of this research is to trace the evolution of the claims used for advertising food products in Italian magazines, by analysing the content and structure of the claims, the target audiences and the elements that have the greatest influence on the presence of the claims in food advertising.

Design/methodology/approach - On the basis of the research conducted by Pratt and Pratt (1995), revised and adapted to the Italian food context, the authors designed a matrix of 1,316 advertisements, which were selected based on the analysis of 67,340 advertisements and using the reference to the food sector as a discriminator. The advertisements were extrapolated from a sample of six Italian magazines, so as to determine the extent to which the various demographic groups in Italy are exposed to print advertising for food, beverages and food supplements. The authors examined the frequency of the relevant advertising forms over a period of four years, from January 2014 to December 2017.

Findings - The results revealed the main types of claims used in the four-year period, as well as the statistically significant differences between the different magazine panels, as concerns the frequency and the types of messages. Moreover, a strong relationship between the number of advertisements in the magazines and the time of the year was also ascertained, as well as significant gender variations.

Originality/value - This study introduces the trends and dynamics of the Italian printed advertising for food to the relevant scientific literature. The results yielded by this research have added further implications and contributions to the existing studies, as concerns claim diffusion based on type, gender and seasonality, and the authors also provide important insights to various socio-economical stakeholders.
\end{abstract}

Keywords Food advertising, Claims, Magazines, Food marketing

Paper type Research paper

\section{Introduction}

In recent years, given the ever more specific demand for healthy and balanced diets, consumers bought more and more food products that are able to satisfy the health-and-wellbeing duo (Anastasiou et al., 2019; Campos et al., 2011; Cecchini and Warin, 2016; Kerr et al., 2015). Consequently, food advertisements became richer in information aimed at satisfying these requirements, and the use of claims became increasingly more frequent. Art. 2, par. 2 of the Regulation (EC) 1924/2006 mentions that "Claim means any message or representation,

(C) Angela Tarabella, Andrea Apicella, Sara Tessitore and Maria Francesca Romano. Published by Emerald Publishing Limited. This article is published under the Creative Commons Attribution (CC BY 4.0) licence. Anyone may reproduce, distribute, translate and create derivative works of this article (for both commercial and non-commercial purposes), subject to full attribution to the original publication and authors. The full terms of this licence may be seen at http://creativecommons.org/licences/by/4.0/ legalcode 
which is not mandatory under Community or national legislation, including pictorial, graphic or symbolic representation, in any form, which states, suggests or implies that a food has particular characteristics". It is precisely this regulation that introduces and clarifies the usage and display requirements for the health and nutrition information to be shown on food products, providing a detailed description of what, how and under what conditions said information should be disclosed to the consumers. The changes in consumption trends and the recent regulation developments have had a profound influence on the communication and marketing models developed by manufacturing companies, the health and nutrition information that is displayed directly on the product packaging, in televised commercials and in print advertising being thoroughly revised. It is worth noting that a study by Livingstone and Helsper (2004) shows that amongst the factors that influence food habits, advertising plays a key role and the food sector is the one that invests the most in advertising tools, as shown by numerous reports (Nielsen, 2018; O’Dowd, 2017; Statista, 2019; Yale Rudd Center, 2014). In Italy too, advertising expenditure in the food and beverage sector amounts to almost $20 \%$ of the total, followed at a considerable distance by the automotive sector $(11.5 \%)$. Television remains the predominant advertising channel, accounting for more than half of the total, while periodicals remain stable in terms of investments, with an overall quota of $6.8 \%$ out of the total (Nielsen, 2018). Similar investment levels and proportions were registered in other European countries and worldwide (Abrahams et al., 2016). Certain studies dive deeper into the communication models and the claims that accompany food and beverage advertisements (insert bibliographical references or delete). The present study sets the objective of analysing the typology of food advertising in Italian magazines based on the methodological approach designed by Pratt and Pratt (1995). The objective of the present study is twofold: first and foremost, to analyse the evolution of food advertising with particular reference to the use of claims, and second, to identify the main differences and significant data related to the types of claims, to gender and to seasonality, by analysing the frequency and content of the advertisements for food products, beverages and food supplements published in six Italian monthly magazines that appeared between January 2014 and December 2017.

\section{Literature review}

Food consumption changed over the past 50 years. Today there are more overweight and obese people in the world than there are underweight or malnourished (Popkin, 2006). In many countries, there is a double burden of undernutrition (from diets that are deficient in energy, micronutrients or both) and overnutrition (energy-dense nutrient-poor diets leading to obesity) (Kearney, 2010). Many changes in food consumption patterns are reflective of the nutrition transition, a series of adverse changes in diet, physical activity and health. Food consumption is variably affected by a whole range of factors including food availability, food accessibility and food choice, which in turn may be influenced by geography, demography, disposable income, socio-economic status (SES), urbanization, globalization, marketing, religion, culture and consumer attitudes (Kearney, 2010). New diets, allergies and food trends have increased the consumers' need for information regarding food products. Indeed, consumers are becoming increasingly aware of health and safety aspects of the food and food products they purchase (Wognum and Bremmers, 2009). Consumer awareness refers to the consumer's knowledge about a particular product. This knowledge allows the consumer to make better, well-informed choices based on information they find trustworthy (Van Trijp and Van der Lans, 2007). Consumer behaviour is not only influenced by the information the consumer has about a certain food product but also by the health image of a food product. The consumer's decision to buy and eat a food product is influenced by many factors and different communication approaches have emerged based on the target audience 
(Pratt and Pratt, 1995). From Nineteens communication, strategies are faced with several challenges, ranging from the heterogeneity of the audience to the consumers demanding certainty and a straightforward message, to the different aims and agendas of the communicators and to the inherent complexity of the scientific message (Celemin and Jung, 2006). Consequently, the number of food products and food products with claims that inform consumers of their health benefits and main features is vastly increasing. Food advertisers use several different advertising claims to express the various benefits of food products, ranging from the convenience of consumption to discount opportunities to claims that emphasize great taste and rich flavours (Fay, 2003). More recently, it has become quite popular amongst food marketers to advertise the health- and nutrition-related benefits as these two issues have become major factors in consumers' food choices (Cervellon and Laurette, 2000; Ippolito and Pappalardo, 2002; Warner, 2006). Food advertisers have adopted various claims to convey product information. Previous studies noted that more than half of the food advertisements contained claims about delicious taste (Ippolito and Pappalardo, 2002; Kim et al., 2009). Due to the accelerated speed of life, food advertising started emphasizing the availability of convenience food products (Chandon and Wansink, 2012; Ippolito and Pappalardo, 2002; Kim et al., 2009) or a new food product (Ippolito and Pappalardo, 2002). Some common food advertising claims highlighted the relative economy of the food product by providing coupon information, for instance (Ippolito and Pappalardo, 2002; Kim et al., 2009), and the idea of enjoying food with family (Cheong et al., 2010). Moreover, with increasing food safety concerns, food brands endeavoured to create a highquality image for their products (Burkitt, 2012). For example, Byrd-Bredbenner and Grasso (2001) and Parker (2003) focussed on the usage of nutrition and health claims in television and magazine advertisements up to 1998 and 2000, respectively. Similarly, Ippolito and Pappalardo (2002) examined advertisements taken from a sample of eight leading magazines between 1977 and 1997, and they observed that the use of different advertising claims appeared to be associated to changes in regulations. They also focussed solely on nutritionand health-related claims. The research by Nocella and Kennedy (2012) examines factors related to the personal characteristics of individuals such as socio-demographic status, knowledge and attitudes and factors pertaining to food and food supplement products, such as the wording of the claims and the communication of the strength and consistency of the scientific evidence. The research on the effects of food claims has concluded that consumers' evaluations of food items are more favourable when claims are presented (Kozup et al., 2003). Other studies demonstrated that consumers tend to rate products more positively and exhibit higher purchasing intention when favourable nutritional information is presented on packaged food labels (Roe et al., 1999; Wansink's, 2003). So food claims are key channels of communication between manufacturers and consumers of packaged food products, and therefore, claims may influence purchase or consumption behaviour, their effect being augmented in the case of less educated consumers. Advertising has always been a crucial marketing tool for the food industry. Food advertising may have an impact on food choices. International evidence suggests that in addition to a number of well-known factors (ethnicity and culture, price, taste, availability, perceived status, food quality, safety and ethical claims, nutritional and health value), food-related advertising seems to be an important factor in people's decision to purchase certain food products (Abrahams et al., 2016). It can help to improve the reputation and sales of a product. Food advertising is an example of an external force designed to influence the outcome of food choice that could influence the market choices. For this reason, many researchers analysed the claims used in food advertising in print media, online and on television. Some studies investigated the information on characterized frequency and type of health and nutrient content claims (Abbatangelo-Gray et al., 2008). Xiaoli et al. (2013) report a content analysis of health- and nutrition-related claims used in food advertisements in popular women's and men's magazines and highlight that the use of
Health claims in Italian magazines 
health- and nutrition-related claims varies across different food groups and types of magazines. Over the years, there have been many studies dedicated to claim analysis; researchers have studied many factors, such as gender, season and others issues that can impact claim efficacy (Adams et al., 2011; Xiaoli et al., 2013). Many researchers analysed the effects of seasons on food advertising. For instance, a study by Adams et al. (2011) reveals that food advertisements were most prevalent in summer, in general interest magazines and in magazines for the most affluent tertile, and least prevalent in spring and in magazines for the least affluent tertile (Adams et al., 2011). Other research shows that some of the variations in food advertising seen across seasons may reflect social and cultural events associated with those seasons. For example, advertisements for alcohol were most prevalent in winter, presumably reflecting the impact of Christmas and New Year festivities, when alcohol consumption tends to peak (Adams et al., 2011; Cho et al., 2001). A study of British women's monthly magazines of the time period 2008/2009 found that food advertising was more prevalent in magazines with an affluent readership and over the summer months, while alcohol advertising peaked over the Christmas period (Spencer et al., 2013). Nevertheless, seasonal variations in food and weight loss messages were particularly strong: excessive eating prevailed in the run-up to Christmas, healthy eating and a more reasonable food pattern was advocated in the months following the New Year, while dieting was dominant in the summer (Spencer et al., 2013). Gender is another item that emerged as "a driver" in food advertising. Differences in gender depiction of gender nonetheless emerge both between magazine types and for all advertising examined (Massè and Rosenblum, 1988). Food advertising in magazines read by women is largely unaffected by the impact on public health of the implementation of current dietary guidelines, as such advertising tends to promote food products of questionable nutritional or health value (Lohmann and Kant, 2000). Various studies of food and beverage marketing in women's magazines have shown that food advertising is dominated by convenience food products, food products high in fat and/or refined sugar and alcoholic beverages, with a widespread lack of advertising of fruits and vegetables (Spencer et al., 2013).

\subsection{Methodological framework}

The methodological framework developed for our investigation is based on a content analysis aimed at identifying the relevant promotional messages in print and at analysing their characteristics. Starting from the aforementioned definition of claims, taken from Reg. 1924/2006 CE referenced above, we referred our analysis to the following three types of claims:

(1) Nutritional claims;

(2) Health claims;

(3) Claims pertaining to the reduction of illness risks.

According to the approach developed by Pratt and Pratt (1995), content analysis was applied to the food advertisements appearing in six Italian magazines. The first phase of the content analysis consisted of the codification of the promotional messages in order to create a specific database, according to the advertisement classification methodology used by Barr (1989), with the necessary adjustments to the Italian food context (for instance, the introduction of the "pasta" category in the "bread and cereals" category). The classification of the messages followed three phases. The first phase was reserved to identifying the frequency with which advertisements and food products, beverages and food integrators were featured in the magazine panel in question. This allowed us to eliminate the messages that were in no way related to the variable food, beverage or nutrition issues. In the second phase, the 
advertisements were divided into 12 product categories, re-elaborated based on the nutritional affinities comprised in the 1995 Pratt and Pratt model, adjusted to reflect the developments of the recent years and the Italian context (Tables 1 and 2).

In the third phase, the nutrition- and health-related messages used for the promotion of the products were divided into six categories: (1) related to general health and nutrition; (2) contain specific nutrients; (3) minimize/eliminate certain substances; (4) consumer related; (5) for weight control and (6) miscellaneous.

Within each of these categories, there are composite claims and promotional messages, given that, for instance, the advertisements that emphasize the low content of certain substances may refer to sugar, calories or fats.

The "General health and nutrition" claim emphasizes the health benefits coming from the use of certain types of products or certain nutrients in that particular product but does not specify the actual illnesses that can be cured or the conditions under which one can benefit from it. In any case the claim remains rather generic, and it often reports doctor recommendations. When the aspect that is emphasized is the presence of specific nutrients in
Health claims in Italian magazines

\begin{tabular}{ll}
\hline Product category & Example \\
\hline Milk and dairy products & Milk, cheese, yogurt and other \\
Bread, cereals and pasta & Bread, flour, cereal, rice, pasta, snack and other \\
Vegetables & Fresh, frozen, canned and other \\
Fruits & Fresh, frozen, canned juice and other \\
Protein-rich foods & Meat, fish, eggs, nuts, soy and other \\
Beverages non-alcoholic & Bottle water, tea, coffee and other \\
Beverages alcoholic & Alcoholic drinks \\
Desserts/food high in fat or & Cakes and cake mix, dessert mix, cookies, ice cream, chocolate, honey and \\
sugar & other \\
Ingredients and condiments & Sauce, pickle, salt and other \\
Miscellaneous & Infant foods, frozen foods, prepared meals and other \\
Dietary supplement & Weight loss supplement, energy bars, whey bars and other \\
\hline
\end{tabular}

Source(s): Our elaboration on Pratt and Pratt (1995)

Table 1 . Product category

\begin{tabular}{|c|c|}
\hline Promotional statement & Claim \\
\hline \multirow[t]{3}{*}{ General health and nutrition } & Good for general health \\
\hline & Health professionals recommend/prevents illness \\
\hline & Easily digested \\
\hline \multirow[t]{3}{*}{ Contain specific nutrients } & Contain vitamins/minerals \\
\hline & Protein-rich food \\
\hline & High in fibres \\
\hline \multirow[t]{4}{*}{ Minimizes/eliminates certain substances } & Natural or pure \\
\hline & Low calories/lean \\
\hline & Sugar free \\
\hline & Low in fat \\
\hline \multirow[t]{3}{*}{ Consumer related } & Taste/smell \\
\hline & Convenient/quick \\
\hline & High-quality goodness \\
\hline For weight control & Weight control \\
\hline Miscellaneous & Miscellaneous \\
\hline
\end{tabular}

Source(s): Our elaboration on Pratt and Pratt (1995)

Table 2.

Promotional statement and claim 
the product, the claim falls in the category: "Contains specific nutrients". This includes various subcategories based on the vitamins, minerals, fibres, carbohydrates and other elements that the product is rich in. The group of products that are advertised as having a minimum level of certain substances or are entirely substance-free falls under "Minimizes/ eliminates certain substances"; this comprises the products presented as having a low content of calories, sugars or fats, the products that are sugar-free or that are pure/natural because they are sold more or less as they are found in nature. Then there is the group "Consumer related", where the product is praised for its taste/aroma, for convenience/speed, for high quality, for being homemade or new, economic or energizing. The advertisements that specify the calorie content are classified as "For weight-control" claims and in general, the packaging mentions the calorie intake or features the phrase "Low calorie content". The last category, "Miscellaneous", includes all the ready-made products or the processed food products that do not belong in any of the other groups. In fact, this category was specifically created to contain all the claims that appear only marginally and sporadically in food advertising, so much so that they constitute a residual category compared to the total number of the messages that were analysed.

Following this scheme, a database was created to include all the advertisements present in our magazine sample, classified according to the categories described above. After the advertisements were collected, the data were processed to determine frequency and the variations registered over the four-year period, depending on gender and season, as well as other statistical information; this allowed us to arrive at a number of conclusions.

The research questions that the study raised were the following:

$R Q 1$. What type of food products, beverages or food supplements were advertised in the six magazines?

$R Q 2$. What was the frequency distribution of the different modes in which food was advertised, and what were the promotional statements regarding food products, beverages and supplements that were used in the magazines?

RQ3. What were the trends and differences between magazines based on audience gender, season and time span?

$R Q 4$. Is there a correspondence between gender, seasonality and claim typology?

\section{Sample and methods}

The claim sample was constituted by analysing the advertisements that appeared in six magazines selected on the basis of readership indexes and reference targets. The readership indexes were extrapolated from the data offered by Audipress, while the reference targets are as follows: two magazines directly dedicated to a general target (Focus and OK Salute e Benessere), two dedicated to women (Cosmopolitan and Starbene) and two dedicated to men (For Men and Men's Health) (see Table 3 for the details about the magazines' diffusion).

The survey period was of four years, from January 2014 to December 2017, in order to identify any changes in advertising messages during the period.

While we were carrying out the research, the magazine Starbene went from being a monthly publication to a weekly one, their number of yearly issues increasing accordingly. In order to avoid distorting the statistic sample, we decided to only analyse the first issue of every month and to omit the following three, after having properly ascertained that the total number of food-related messages had remained relatively stable. This allowed us to continue our research until the end of 2017 without affecting the validity of the statistic sample. 


\begin{tabular}{|c|c|c|c|c|c|c|}
\hline Type & $\begin{array}{l}\text { Name of } \\
\text { magazine }\end{array}$ & $\begin{array}{c}\mathrm{N}^{\circ} \text { of copies sold } \\
\text { for issues } \\
\text { (January 2014) } \\
\end{array}$ & $\begin{array}{c}\mathrm{N}^{\circ} \text { of copies sold } \\
\text { for issues } \\
\text { (January 2015) } \\
\end{array}$ & $\begin{array}{c}\mathrm{N}^{\circ} \text { of copies sold } \\
\text { for issues } \\
\text { (January 2016) }\end{array}$ & $\begin{array}{c}\mathrm{N}^{\circ} \text { of copies sold } \\
\text { for issues } \\
\text { (January 2017) } \\
\end{array}$ & $\begin{array}{l}\text { Health claims } \\
\text { in Italian } \\
\text { magazines }\end{array}$ \\
\hline \multirow{2}{*}{$\begin{array}{l}\text { General } \\
\text { target }\end{array}$} & Focus & 369.794 & 372.770 & 307.259 & 299.850 & \\
\hline & $\begin{array}{l}\text { Ok Salute e } \\
\text { Benessere }\end{array}$ & 121.450 & 121.469 & 112.180 & 94.600 & \\
\hline Women & $\begin{array}{l}\text { Cosmopolitan } \\
\text { Starbene }\end{array}$ & $\begin{array}{l}232.974 \\
141.766\end{array}$ & $\begin{array}{l}170.576 \\
*\end{array}$ & $\begin{array}{c}138.114 \\
*\end{array}$ & $\begin{array}{c}124.765 \\
*\end{array}$ & \\
\hline \multirow[t]{2}{*}{ Men } & $\begin{array}{l}\text { For Men } \\
\text { Magazine }\end{array}$ & 84.000 & 72.057 & 76.577 & 61.100 & \\
\hline & Men's Health & $*$ & $40.000 * *$ & $*$ & $*$ & \\
\hline \multicolumn{6}{|c|}{$\begin{array}{l}\text { Source(s): Agenzia Diffusione Stampa website Http://www.adsnotizie.it/ Consulted on 15/07/2019 } \\
\text { * Data not available } \\
\text { ** Data provided by the editors of the publishing houses }\end{array}$} & $\begin{array}{r}\text { Table } 3 \\
\text { Magazines by type and } \\
\text { diffusion (source 2019) }\end{array}$ \\
\hline
\end{tabular}

The selection of the magazines was done after a manual analysis of those with the highest content of messages specifically dedicated to food, with the exclusion of those that are strictly dedicated to cooking and recipes. The coding process was managed by several people in order to insure the comparability of the results obtained; a sample of coded items was selected, coded by a third person and the results were compared. A random sample of items (approximately 10\%) selected from each coder's portion was then recoded by a second coder. Intercoder reliability was assessed with Krippendorff's $\alpha$, using a bootstrap method (Hayes and Krippendorff, 2007). The survey period was of four years, from January 2014 to December 2017, in order to identify any changes in advertising messages during that period. The resulting data set is a matrix of 1,316 advertisements with 11 variables (product, product category, type of food promotional statement, claim, magazine, month, season [by semester], season, food supplements, year, target), representing about $15 \%$ of all the advertisements in the selected magazines.

The matrix of collected data was then processed using SAS 9.4 software (the "OnDemand for Academics" version), yielding both a descriptive analysis and a multidimensional analysis. Cross tabulations (Proc FREQ) were also conducted between two or three variables, so as to test the significance of their association by means of chi-square statistics. In order to obtain a multidimensional description of the data set, a correspondence analysis was conducted (Proc CORRESP) (Greenacre, 1994; Lebart et al., 1984).

\section{Results}

\subsection{The most advertised products and their categories}

The analysis of the six magazines showed that there was substantial stability over the period covered by the research in terms of the number of advertisements dedicated to food products (see Table 4).

The only registered variation was the $35 \%$ decrease in food advertisements in 2016 compared to the previous year, a drop that was quickly recovered in 2017, which proves that the industry has a constant interest in this type of advertising.

The magazines are different from each other in terms of the number of messages they contain. The largest contribution was that of Starbene, a magazine that published $33.5 \%$ of all the food advertisements in the six magazines, their advertisements being dedicated to the topics of health, well-being and nutrition. The other magazines that made important contributions were For Men and OK Salute e Benessere, accounting for 23 and $21 \%$ of the 


\begin{tabular}{|c|c|c|c|c|c|c|c|c|}
\hline $\mathrm{BFJ}$ & Year & Starbene & For Men & OK Salute & $\begin{array}{l}\text { Magazine } \\
\text { Focus }\end{array}$ & Men's Health & Cosmopolitan & $\begin{array}{c}\% \\
\text { Total } \\
\end{array}$ \\
\hline & 2014 & 129 & 95 & 100 & 39 & 21 & 2 & 386 \\
\hline & & 33.42 & 24.61 & 25.91 & 10.10 & 5.44 & 0.52 & \\
\hline & & 29.32 & 31.77 & 36.90 & 21.79 & 19.44 & 10.53 & \\
\hline & 2015 & 177 & 55 & 51 & 40 & 33 & 5 & 361 \\
\hline & & 49.03 & 15.24 & 14.13 & 11.08 & 9.14 & 1.39 & \\
\hline & & 40.23 & 18.39 & 18.82 & 22.35 & 30.56 & 26.32 & \\
\hline \multirow{9}{*}{$\begin{array}{l}\text { Table } 4 \text {. } \\
\text { Magazine by year }\end{array}$} & 2016 & 63 & 46 & 48 & 46 & 31 & 0 & 234 \\
\hline & & 26.92 & 19.66 & 20.51 & 19.66 & 13.25 & 0.00 & \\
\hline & & 14.32 & 15.38 & 17.71 & 25.70 & 28.70 & 0.00 & \\
\hline & 2017 & 71 & 103 & 72 & 54 & 23 & 12 & 335 \\
\hline & & 21.19 & 30.75 & 21.49 & 16.12 & 6.87 & 3.58 & \\
\hline & & 16.14 & 34.45 & 26.57 & 30.17 & 21.30 & 63.16 & \\
\hline & Total & 440 & 299 & 271 & 179 & 108 & 19 & 1,316 \\
\hline & & $33.43 \%$ & $22.72 \%$ & $20.59 \%$ & $13.16 \%$ & $8.2 \%$ & $1.44 \%$ & $100 \%$ \\
\hline & \multicolumn{8}{|c|}{ Note(s): Sample size $=1,316$} \\
\hline
\end{tabular}

advertisements, respectively. The number of food advertisements published in Men's Health and Cosmopolitan is negligible, with 8.20 and $1.44 \%$, respectively.

Of the six publications, two showed an oscillating pace in the promotion of food products and beverages: For Men and OK Salute registered a decrease in food advertisements in 2015 and 2016, but in 2017, the frequency of this type of advertising increased. In both cases, although the respective publications have different targets, the year 2016 marked the reduction of food and beverage insertions by almost half, while 2017 marked a strong recovery which, in the case of For Men, actually surpassed the initial level of 2014. Some variations were also recorded in the case of Men's Health, although its evolution is opposed to that of the previously mentioned magazines. The data concerning food advertisements increased in 2015 and 2016, a trend which is opposed to OK Salute and For Men. A certain variation was also registered by Starbene, which shows a high volume of food advertising in 2015 , followed by a steep decline in 2016 and a slight recovery in 2017. This evolution may be related to corporate communication strategies. Corporations periodically change their communication instruments in order to reach specific consumer target groups. However, Focus and Cosmopolitan published steadily increasing numbers of food and beverage advertisements, although the numbers in themselves are less consequent than in the case of the other magazines. The variation registered in 2016-2017 followed the national evolution of print advertising expenditure, which decreased in 2017 by $6 \%$, with different variation ratios for some sectors; for instance, food advertising decreased by $3 \%$. On the whole, there is a statistically significant association between the magazines and the years taken into consideration (chi-square $=118.25$; $\mathrm{df}=15 ; p<0.0001$ ).

Analysing the distribution of advertisements by product category (see Table 5), there are significant differences between the years and different degrees of incidence on the total (chisquare $=70.46 ; \mathrm{df}=11 ; p<0.0001$ ). Some of the most advertised products are dietary supplements, representing about $38 \%$ of all the advertisements (511 messages out of 1,316), even though there is a progressive decline from 2014 to $2017(-56.5 \%)$. Out of the total number of dietary product advertisements, around $26.5 \%$ were featured in For Men, while another $27 \%$ appeared in OK Salute e Benessere. The latter published the most supplement and dietary product advertisements in 2014 and 2015, a trend which decreased over the following years. A different case is that of For Men, which published many advertisements from this category in 2014 and again in 2017, as if there were a renewed interest on the part of 


\begin{tabular}{|c|c|c|c|c|c|c|}
\hline Product_category & 2014 & 2015 & 2016 & 2017 & Total & Ith claim \\
\hline Dietary supplement suggested for alimentary supplement diets & $\begin{array}{l}174 \\
34.05 \\
45.08\end{array}$ & $\begin{array}{c}134 \\
26.22 \\
37.12\end{array}$ & $\begin{array}{l}92 \\
18.00 \\
3932\end{array}$ & $\begin{array}{l}111 \\
21.72 \\
3313\end{array}$ & 511 & magazines \\
\hline Beverages non-alcoholic & $\begin{array}{l}4500 \\
55 \\
27.50 \\
14.25\end{array}$ & $\begin{array}{l}67 \\
33.50 \\
18.56\end{array}$ & $\begin{array}{l}41.02 \\
40.50 \\
17.52\end{array}$ & $\begin{array}{l}3.10 \\
37 \\
18.50 \\
11.04\end{array}$ & 200 & \\
\hline Milk and dairy products & $\begin{array}{l}25 \\
21.01 \\
6.48\end{array}$ & $\begin{array}{l}40 \\
33.61 \\
11.08\end{array}$ & $\begin{array}{l}27 \\
22.69 \\
11.54\end{array}$ & $\begin{array}{l}27 \\
22.69 \\
8.06\end{array}$ & 119 & \\
\hline Miscellaneous & $\begin{array}{l}15 \\
16.48 \\
3.89\end{array}$ & $\begin{array}{l}26 \\
28.57 \\
7.20\end{array}$ & $\begin{array}{l}25 \\
27.47 \\
10.68\end{array}$ & $\begin{array}{l}25 \\
27.47 \\
7.46\end{array}$ & 91 & \\
\hline Bread, cereals and pasta & $\begin{array}{l}26 \\
31.71 \\
6.74\end{array}$ & $\begin{array}{l}32 \\
39.02 \\
8.86\end{array}$ & $\begin{array}{r}12 \\
14.63 \\
5.13\end{array}$ & $\begin{array}{c}12 \\
14.63 \\
3.58\end{array}$ & 82 & \\
\hline Desserts/foods high in fat or sugar & $\begin{array}{l}21 \\
31.34 \\
5.44\end{array}$ & $\begin{array}{l}6 \\
8.96 \\
1.66\end{array}$ & $\begin{array}{l}10 \\
14.93 \\
4.27\end{array}$ & $\begin{array}{l}30 \\
44.78 \\
8.96\end{array}$ & 67 & \\
\hline Ingredients and condiments & $\begin{array}{l}26 \\
44.07 \\
6.74\end{array}$ & $\begin{array}{l}17 \\
28.81 \\
4.71\end{array}$ & $\begin{array}{l}4 \\
6.78 \\
1.71\end{array}$ & $\begin{array}{l}12 \\
20.34 \\
3.58\end{array}$ & 59 & \\
\hline Protein-rich food & $\begin{array}{l}23 \\
38.98 \\
5.96\end{array}$ & $\begin{array}{l}14 \\
23.73 \\
3.88\end{array}$ & $\begin{array}{l}12 \\
20.34 \\
5.13\end{array}$ & $\begin{array}{l}10 \\
16.95 \\
2.99\end{array}$ & 59 & \\
\hline Beverages alcoholic & $\begin{array}{c}7 \\
12.50 \\
1.81\end{array}$ & $\begin{array}{l}12 \\
21.43 \\
3.32\end{array}$ & $\begin{array}{l}2 \\
3.57 \\
0.85\end{array}$ & $\begin{array}{l}35 \\
62.50 \\
10.45\end{array}$ & 56 & \\
\hline Vegetables & $\begin{array}{c}7 \\
16.28 \\
1.81\end{array}$ & $\begin{array}{l}11 \\
25.58 \\
3.05\end{array}$ & $\begin{array}{l}3 \\
6.98 \\
1.28\end{array}$ & $\begin{array}{l}22 \\
51.16 \\
6.57\end{array}$ & 43 & \\
\hline Fruits & $\begin{array}{c}7 \\
24.14 \\
1.81\end{array}$ & $\begin{array}{l}2 \\
6.90 \\
0.55\end{array}$ & $\begin{array}{c}6 \\
20.69 \\
2.56\end{array}$ & $\begin{array}{l}14 \\
48.28 \\
4.18\end{array}$ & 29 & \\
\hline $\begin{array}{l}\text { Total } \\
\text { Note(s): Sample size }=1,316\end{array}$ & 386 & 361 & 234 & 335 & 1,316 & $\begin{array}{r}\text { Product category } \\
\text { by year }\end{array}$ \\
\hline
\end{tabular}

the readers. With notably smaller, yet significant numbers, we must also note the strong contribution of the advertisements aimed at the promotion of non-alcoholic drinks $(15.2 \%)$ and milk and dairy products $(9.0 \%)$. The presence of these products in the magazines that we analysed grew significantly in 2015 and then decreased in the last two years of the period under consideration. A little less than half of the non-alcoholic beverage advertisements were published in Starbene, especially in 2015 and only occasionally in 2017. Milk and dairy products were also mainly advertised in health-oriented magazines (Starbene and OK Salute e Benessere) and are only rarely advertised in the other four magazines. The advertising space dedicated to bread and pasta strongly decreased, with a variation of more than $50 \%$ between 2014 and 2017. 2017 marked a steep increase in advertisements for products such as desserts and alcoholic drinks, which, in the overall analysis, have a comparatively small incidence on the total ( 5 and $4 \%$, respectively), but their contribution was larger in 2017 , namely $20 \%$ for desserts and $17 \%$ for alcoholic drinks. The advertisements dedicated to single ingredients also registered a sharp decrease, like protein-rich food, the presence of which dropped to half between 2014 and 2017. 
Various studies confirm that, as far as food advertising is concerned, the seasonal factor is one of the most impactful, together with the reference target (Adams et al., 2011). In Table 6, we analysed product categories by season. For more clarity, the seasons were grouped together as fall-winter and spring-summer. It is immediately obvious how the frequency of the advertisements for different product categories mirrors the season; for instance, ice cream is advertised much more in spring-summer and alcoholic beverages in fall-winter. As a confirmation thereof, our data regarding food supplements show that $63 \%$ of the advertising for this kind of product is published in the spring-summer season. On the other hand, as shown above, the cold season is the ideal period to promote alcoholic beverages. In total, $78 \%$ of the advertisements that promote drinks such as wine, beer, champagne, etc. are featured in magazines published in the fall-winter months, while $54 \%$ of dairy and milk advertisements also appear during the cold season.

Similarly to seasonality, gender too is one of the factors that have the greatest influence on advertising, a tendency confirmed by British studies (Adams and Whit, 2011). As early as the

Frequency

\begin{tabular}{|c|c|c|c|}
\hline $\begin{array}{l}\quad \text { Product_category } \\
\text { Frequency } \\
\text { Pct Riga } \\
\text { Pct col } \\
\end{array}$ & Summer/spring & Fall/winter & Total \\
\hline Dietary supplement & $\begin{array}{l}322 \\
63.01 \\
47.08\end{array}$ & $\begin{array}{c}189 \\
36.99 \\
29.91\end{array}$ & 511 \\
\hline Beverages non-alcoholic & $\begin{array}{l}102 \\
51.00 \\
14.91\end{array}$ & $\begin{array}{l}98 \\
49.00 \\
15.51\end{array}$ & 200 \\
\hline Milk and dairy products & $\begin{array}{l}54 \\
45.38 \\
7.89\end{array}$ & $\begin{array}{l}65 \\
54.62 \\
10.28\end{array}$ & 119 \\
\hline Miscellaneous & $\begin{array}{l}38 \\
41.76 \\
5.56\end{array}$ & $\begin{array}{l}53 \\
58.24 \\
8.39\end{array}$ & 91 \\
\hline Bread, cereals and pasta & $\begin{array}{l}45 \\
54.88 \\
6.58\end{array}$ & $\begin{array}{l}37 \\
45.12 \\
5.85\end{array}$ & 82 \\
\hline Desserts/foods high in fat or sugar & $\begin{array}{l}30 \\
44.78 \\
4.39\end{array}$ & $\begin{array}{l}37 \\
55.22 \\
5.85\end{array}$ & 67 \\
\hline Ingredients and condiments & $\begin{array}{l}23 \\
38.98 \\
3.36\end{array}$ & $\begin{array}{l}36 \\
61.02 \\
5.70\end{array}$ & 59 \\
\hline Protein-rich food & $\begin{array}{l}30 \\
50.85 \\
4.39\end{array}$ & $\begin{array}{l}29 \\
49.15 \\
4.59\end{array}$ & 59 \\
\hline Beverages alcoholic & $\begin{array}{l}12 \\
21.43 \\
1.75\end{array}$ & $\begin{array}{l}44 \\
78.57 \\
6.96\end{array}$ & 56 \\
\hline Vegetables & $\begin{array}{l}14 \\
32.56 \\
2.05\end{array}$ & $\begin{array}{l}29 \\
67.44 \\
4.59\end{array}$ & 43 \\
\hline Fruits & $\begin{array}{l}14 \\
48.28 \\
2.05\end{array}$ & $\begin{array}{l}15 \\
51.72 \\
2.37\end{array}$ & 29 \\
\hline $\begin{array}{l}\text { Total } \\
\text { Note(s): Sample size }=1,316\end{array}$ & 684 & 632 & 1,316 \\
\hline
\end{tabular}

Table 6.

Product category by season

Note(s): Sample size $=1,316$ 
1980s, Silverstein et al. (1986) determined that women's magazines contained significantly more diet product advertisements than men. Furthermore, 20 years later, Gough (2007) reports that magazine advertising tends to target women as experts in healthy dieting and men as indifferent to healthy food. The present study also confirms that food advertising is primarily addressed to women, as demonstrated by the statistically significant data contained in Table 7. An aspect that undoubtedly contributed to this result was the choice of magazines; of the six publications, two are purely masculine. In the table below, we have distributed the products by category and reference target. Apart from men and women, a generic target was included, associated with products that are not gender specific. The percentiles are rather similar, namely $35 \%$ women, $34 \%$ generic and $31 \%$ men. This finding is surprising, in that the food products reserved for men only represent $31 \%$, when two of the magazines under analysis have an exclusively male readership. The product category that bucks this trend regards food supplements, more than $40 \%$ of supplement advertisements
Frequency

Product_category

Pct Riga

Pct col

Dietary supplement

Beverages non-alcoholic

Milk and dairy products

Miscellaneous

Bread, cereals and pasta

Desserts/foods high in fat or sugar

Ingredients and condiments

Protein-rich food

Beverages alcoholic

(2)

Vegetables

Fruits

Note(s): Sample size $=1,316$
Target

\begin{tabular}{|c|c|c|c|}
\hline Women & Generic for everyone & Men & Total \\
\hline 134 & 170 & 207 & 511 \\
\hline 26.22 & 33.27 & 40.51 & \\
\hline 28.94 & 38.03 & 50.99 & \\
\hline 100 & 84 & 16 & 200 \\
\hline 50.00 & 42.00 & 8.00 & \\
\hline 21.60 & 18.79 & 3.94 & \\
\hline 65 & 38 & 16 & 119 \\
\hline 54.62 & 31.93 & 13.45 & \\
\hline 14.04 & 8.50 & 3.94 & \\
\hline 27 & 38 & 26 & 91 \\
\hline 29.67 & 41.76 & 28.57 & \\
\hline 5.83 & 8.50 & 6.40 & \\
\hline 44 & 21 & 17 & 82 \\
\hline 53.66 & 25.61 & 20.73 & \\
\hline 9.50 & 4.70 & 4.19 & \\
\hline 24 & 22 & 21 & 67 \\
\hline 35.82 & 32.84 & 31.34 & \\
\hline 5.18 & 4.92 & 5.17 & \\
\hline 25 & 15 & 19 & 59 \\
\hline 42.37 & 25.42 & 32.20 & \\
\hline 5.40 & 3.36 & 4.68 & \\
\hline 15 & 24 & 20 & 59 \\
\hline 25.42 & 40.68 & 33.90 & \\
\hline 3.24 & 5.37 & 4.93 & \\
\hline 3 & 6 & 47 & 56 \\
\hline 5.36 & 10.71 & 83.93 & \\
\hline 0.65 & 1.34 & 11.58 & \\
\hline 12 & 15 & 16 & 43 \\
\hline 27.91 & 34.88 & 37.21 & \\
\hline 2.59 & 3.36 & 3.94 & \\
\hline 14 & 14 & 1 & 29 \\
\hline 48.28 & 48.28 & 3.45 & \\
\hline 3.02 & 3.13 & 0.25 & \\
\hline 463 & 447 & 406 & 1,316 \\
\hline
\end{tabular}

Table 7. egory by target 
being addressed to men (40.5\%). A similar trend regards alcoholic drinks advertisements, which are addressed exclusively to men (84\%). As concerns the other main product categories, women remain the preferred target audience, as is the case for non-alcoholic drinks, milk and dairy, bread and pasta. The 59 advertisements in the category "protein-rich food" are mainly directed at a generic or mostly male target audience. Smaller differences were recorded for other products, like desserts or ingredients (see Table 8).

The data for food supplements show a preponderance of food advertisements during the cold season, while in spring and summer, there are no notable differences between food products and food supplements, which confirms that food supplements are mostly bought when summer is near.

\subsection{From promotional statements to claims}

The research then continued with the analysis of the promotional statements (see Table 9). We noted that the majority of the statements pertain to the first three entries in the following table ("consumer related", "contains specific nutrients" and "good for general health and nutrition"), while the other claims that are the object of the survey, including "minimizes/ eliminates certain substances" and "for weight control", are less frequent. The item "Miscellaneous" contains products that do not fall under any of the other categories. Table 9 also shows that there is a statistically significant variation between promotional statements and seasons (chi-square $=72.95 ; \mathrm{df}=5 ; p<0.0001$ ).

The research further focussed on the claims that are subcategories generated by the promotional statements (see Table 10). The association between year and claim also proved statistically significant (chi-square $=310.57$; df $=30 ; p<0.0001$ ). Starting from the statements, we established 17 different claims, each with different contents. The yearly frequency of each of these 17 claims was then analysed. The claim that was most frequently encountered in the analysed advertisements was tastelsmell, present in $30.85 \%$ of the messages. The second and third most used claims are contains vitamins iminerals and good for general health, present in 16.79 and $13.15 \%$ of all the messages, respectively. The last claim to have a significant presence is weight control, present in $10.49 \%$ of all advertisements. The other claims proved to be less frequently used. In terms of yearly distribution, the claim tastelsmell proved to be on a steeply growing trend, going from a relatively stable occurrence rate in the first three years of the analysis (68 occurrences in 2014, 78 in 2015, 53 in 2016) to 207 occurrences in 2017. The use of the claims good for general health and weight control has gone down in the lapse of time between 2014 and 2017.

Claims too are influenced by seasonality (see Table 11): tastelsmell, which is the claim most used for the promotion of food products, appeared 406 times, a staggering 278 occurrences -

Table 8.

Differences between food and supplement product in the seasons

\begin{tabular}{lccc}
\hline Food_supplement & & Season & \\
Frequency & & & \\
Pct Riga & Summer/spring & Fall/winter & Total \\
Pct col & 355 & 443 & 798 \\
\hline Food & 44.49 & 55.51 & \\
& 51.90 & 70.09 & 518 \\
Supplement & 329 & 189 & \\
& 63.51 & 29.49 & 1,316 \\
Total & 48.10 & 632 & \\
Note(s): Sample size $=1,316$ & 684 & &
\end{tabular}




\begin{tabular}{|c|c|c|c|c|}
\hline$\underline{\text { Promotional_statement }}$ & Summer/spring & $\begin{array}{l}\text { Season } \\
\text { Fall/winter }\end{array}$ & Total & $\begin{array}{l}\text { Health claims } \\
\text { in Italian }\end{array}$ \\
\hline Consumer related & $\begin{array}{l}159 \\
12.08 \\
34.27 \\
23.25\end{array}$ & $\begin{array}{l}305 \\
23.18 \\
65.73 \\
48.26\end{array}$ & $\begin{array}{l}464 \\
35.26\end{array}$ & \\
\hline Contains specific nutrients & $\begin{array}{c}208 \\
15.81 \\
61.18 \\
30.41\end{array}$ & $\begin{array}{c}132 \\
10.03 \\
38.82 \\
20.89\end{array}$ & $\begin{array}{l}340 \\
25.84\end{array}$ & \\
\hline General health and nutrition & $\begin{array}{c}169 \\
12.84 \\
62.59 \\
24.71\end{array}$ & $\begin{array}{r}101 \\
7.67 \\
37.41 \\
15.98\end{array}$ & $\begin{array}{l}270 \\
20.52\end{array}$ & \\
\hline For weight control & $\begin{array}{c}86 \\
6.53 \\
62.32 \\
12.57\end{array}$ & \begin{tabular}{r}
\multicolumn{1}{c}{52} \\
3.95 \\
37.68 \\
8.23
\end{tabular} & $\begin{array}{l}138 \\
10.49\end{array}$ & \\
\hline Minimizes/eliminates certain substances & \begin{tabular}{r}
\multicolumn{1}{c}{42} \\
3.19 \\
58.33 \\
6.14
\end{tabular} & $\begin{array}{r}30 \\
2.28 \\
41.67 \\
4.75\end{array}$ & $\begin{array}{l}72 \\
5.47\end{array}$ & \\
\hline Miscellaneous & $\begin{array}{r}20 \\
1.52 \\
62.50 \\
2.92\end{array}$ & $\begin{array}{r}12 \\
0.91 \\
37.50 \\
1.90\end{array}$ & $\begin{array}{l}32 \\
2.43\end{array}$ & \\
\hline Total & $\begin{array}{l}684 \\
51.98\end{array}$ & $\begin{array}{l}632 \\
48.02\end{array}$ & $\begin{array}{c}1,316 \\
100.00\end{array}$ & Table 9. \\
\hline Note(s): Sample size $=1,316$ & & & & Statement by season \\
\hline
\end{tabular}

which corresponds to $68 \%$ of the total - being published in the warm season, and only 128 occurrences, that is $32 \%$, pertaining to the cold season. Contains vitamins/minerals is preferred in the warm season too, with 148 occurrences, compared to 73 in the cold season, numbers which represent 67 and $33 \%$ of the total, respectively. A similar, albeit less marked, tendency was registered for good for general health and weight control. Good for general health was present in 107 messages during summer and 66 during winter, while weight control appeared in 86 messages in the summer and 52 in winter. There is a positive significance for this relationship too.

\subsection{Multidimensional analysis}

Given the dispersion and the numerousness of the variables available for each message, we proceeded to a multidimensional correspondence analysis, in which we used as variables the food supplement, the target, the season, the year and the promotional statement, using the latter as additional variable with a two-dimensional resolution. We thus obtained the Cartesian coordinate system representation reported below as Figure 1.

The closeness of the variables shows a correlation, especially in 2014, between advertisements targeting men related to the category "dietary supplement" and regarding food supplements. On the opposite slope, there are the advertisements targeting women, with a larger presence in 2015 and associated to claims like minimizesleliminates certain substances. The years 2016 and 2017 are mainly characterized by messages aimed at a generic audience, especially during the cold season. 
BFJ

\begin{tabular}{|c|c|c|c|c|c|}
\hline \multirow[b]{2}{*}{ Claim } & \multicolumn{4}{|c|}{ Year } & \multirow[b]{2}{*}{ Total } \\
\hline & 2014 & 2015 & 2016 & 2017 & \\
\hline \multirow[t]{4}{*}{ Taste/smell } & 68 & 78 & 53 & 207 & 406 \\
\hline & 5.17 & 5.93 & 4.03 & 15.73 & 30.85 \\
\hline & 16.75 & 19.21 & 13.05 & 50.99 & \\
\hline & 17.62 & 21.61 & 22.65 & 61.79 & \\
\hline \multirow[t]{4}{*}{ Contains vitamins/minerals } & 46 & 56 & 49 & 70 & 221 \\
\hline & 3.50 & 4.26 & 3.72 & 5.32 & 16.79 \\
\hline & 20.81 & 25.34 & 22.17 & 31.67 & \\
\hline & 11.92 & 15.51 & 20.94 & 20.90 & \\
\hline \multirow[t]{4}{*}{ Good for general health } & 72 & 50 & 31 & 20 & 173 \\
\hline & 5.47 & 3.80 & 2.36 & 1.52 & 13.15 \\
\hline & 41.62 & 28.90 & 17.92 & 11.56 & \\
\hline & 18.65 & 13.85 & 13.25 & 5.97 & \\
\hline \multirow{4}{*}{ Weight control } & 43 & 56 & 28 & 11 & 138 \\
\hline & 3.27 & 4.26 & 2.13 & 0.84 & 10.49 \\
\hline & 31.16 & 40.58 & 20.29 & 7.97 & \\
\hline & 11.14 & 15.51 & 11.97 & 3.28 & \\
\hline \multirow[t]{4}{*}{ High in fibres } & 34 & 27 & 12 & 3 & 76 \\
\hline & 2.58 & 2.05 & 0.91 & 0.23 & 5.78 \\
\hline & 44.74 & 35.53 & 15.79 & 3.95 & \\
\hline & 8.81 & 7.48 & 5.13 & 0.90 & \\
\hline \multirow[t]{4}{*}{ Health professional recommends } & 23 & 20 & 13 & 2 & 58 \\
\hline & 1.75 & 1.52 & 0.99 & 0.15 & 4.41 \\
\hline & 39.66 & 34.48 & 22.41 & 3.45 & \\
\hline & 5.96 & 5.54 & 5.56 & 0.60 & \\
\hline \multirow[t]{4}{*}{ High-quality goodness } & 28 & 16 & 9 & 1 & 54 \\
\hline & 2.13 & 1.22 & 0.68 & 0.08 & 4.10 \\
\hline & 51.85 & 29.63 & 16.67 & 1.85 & \\
\hline & 7.25 & 4.43 & 3.85 & 0.30 & \\
\hline \multirow[t]{4}{*}{ Protein-rich food } & 15 & 20 & 6 & 0 & 41 \\
\hline & 1.14 & 1.52 & 0.46 & 0.00 & 3.12 \\
\hline & 36.59 & 48.78 & 14.63 & 0.00 & \\
\hline & 3.89 & 5.54 & 2.56 & 0.00 & \\
\hline \multirow[t]{4}{*}{ Low calorie/lean } & 9 & 17 & 6 & 3 & 35 \\
\hline & 0.68 & 1.29 & 0.46 & 0.23 & 2.66 \\
\hline & 25.71 & 48.57 & 17.14 & 8.57 & \\
\hline & 2.33 & 4.71 & 2.56 & 0.90 & \\
\hline \multirow[t]{4}{*}{ Miscellaneous } & 9 & 5 & 11 & 7 & 32 \\
\hline & 0.68 & 0.38 & 0.84 & 0.53 & 2.43 \\
\hline & 28.13 & 15.63 & 34.38 & 21.88 & \\
\hline & 2.33 & 1.39 & 4.70 & 2.09 & \\
\hline \multirow[t]{4}{*}{ Easily digested } & 15 & 6 & 2 & 1 & 24 \\
\hline & 1.14 & 0.46 & 0.15 & 0.08 & 1.82 \\
\hline & 62.50 & 25.00 & 8.33 & 4.17 & \\
\hline & 3.89 & 1.66 & 0.85 & 0.30 & \\
\hline \multirow{4}{*}{ Natural or pure } & 5 & 2 & 5 & 9 & 21 \\
\hline & 0.38 & 0.15 & 0.38 & 0.68 & 1.60 \\
\hline & 23.81 & 9.52 & 23.81 & 42.86 & \\
\hline & 1.30 & 0.55 & 2.14 & 2.69 & \\
\hline \multirow{5}{*}{ Hair growth } & 8 & 2 & 5 & 0 & \\
\hline & 0.61 & 0.15 & 0.38 & 0.00 & 1.14 \\
\hline & 53.33 & 13.33 & 33.33 & 0.00 & \\
\hline & 2.07 & 0.55 & 2.14 & 0.00 & \\
\hline & \multicolumn{5}{|c|}{ (continued) } \\
\hline
\end{tabular}

Table 10.

Claim per year 


\begin{tabular}{|c|c|c|c|c|c|c|}
\hline & & & & & & ealth claims \\
\hline Claim & 2014 & 2015 & 2016 & 2017 & Total & in Italian \\
\hline Low in fat & 5 & 0 & 2 & 1 & 8 & \\
\hline & 0.38 & 0.00 & 0.15 & 0.08 & 0.61 & \\
\hline & 62.50 & 0.00 & 25.00 & 12.50 & & \\
\hline & 1.30 & 0.00 & 0.85 & 0.30 & & \\
\hline Sugar free & 2 & 4 & 2 & 0 & 8 & \\
\hline & 0.15 & 0.30 & 0.15 & 0.00 & 0.61 & \\
\hline & 25.00 & 50.00 & 25.00 & 0.00 & & \\
\hline & 0.52 & 1.11 & 0.85 & 0.00 & & \\
\hline Convenient/quick & 4 & 0 & 0 & 0 & 4 & \\
\hline & 0.30 & 0.00 & 0.00 & 0.00 & 0.30 & \\
\hline & 100.00 & 0.00 & 0.00 & 0.00 & & \\
\hline & 1.04 & 0.00 & 0.00 & 0.00 & & \\
\hline Contains specific fat & 0 & 2 & 0 & 0 & 2 & \\
\hline & 0.00 & 0.15 & 0.00 & 0.00 & 0.15 & \\
\hline & 0.00 & 100.00 & 0.00 & 0.00 & & \\
\hline & 0.00 & 0.55 & 0.00 & 0.00 & & \\
\hline Total & 386 & 361 & 234 & 335 & 1,316 & \\
\hline & 29.33 & 27.43 & 17.78 & 25.46 & 100.00 & \\
\hline & or the clai & ble with $\mathrm{r}$ & $t$ to year & & & \\
\hline Statistics & $\mathrm{DF}$ & & Value & & Prob & \\
\hline Warning: $32 \%$ of the cells have & counts le & an 5 . The & quared $\mathrm{m}$ & be a val & & \\
\hline Chi-squared & 48 & & 348.2189 & & $<0.0001$ & \\
\hline Chi-squared rapp verosim & 48 & & 373.1669 & & $<0.0001$ & \\
\hline Chi-squared MH & 1 & & 102.4436 & & $<0.0001$ & \\
\hline Phi coefficient & & & 0.5144 & & & \\
\hline Contingency coefficient & & & 0.4574 & & & \\
\hline Cramér's $V$ & & & 0.2970 & & & \\
\hline Note(s): Sample size $=1,316$ & & & & & & Table 10. \\
\hline
\end{tabular}

\section{Discussion/conclusions}

The study analyses the types of food products, beverages and food integrators advertised over the four-year period in the six selected magazines. Some indications for the revision of advertising messages, of nutrition-related information and of the food products advertised by the industry were yielded by the study. First and foremost, the study throws into sharp relief the need to communicate with a greater degree of precision not only the type of product and the corresponding characteristic (for instance, how much of a particular nutrient the product contain or that it is free of a certain substance) but also the relative health benefits. The consumer may benefit either by acquiring greater knowledge and education in terms of food behaviour or from the actual use of the product. A second important indication is related to the seasonality of the products, which is very marked for some types of claims, but which can be greatly improved for certain references that are still little representative, although strongly season dependent. Finally, regarding gender differences, there are still ample margins for intervention as concerns the targeting of advertising towards men or women, even though the study shows a progressive closing of the gap between the consumption models for many products, first amongst them being food supplements. Corporate efforts should aim at improving the food and nutrition habits of the consumers, a result which could be obtained by the convergent efforts of companies to put out better promotional messages and of the policymakers to encourage the improvement of the quality of food products and the 
BFJ

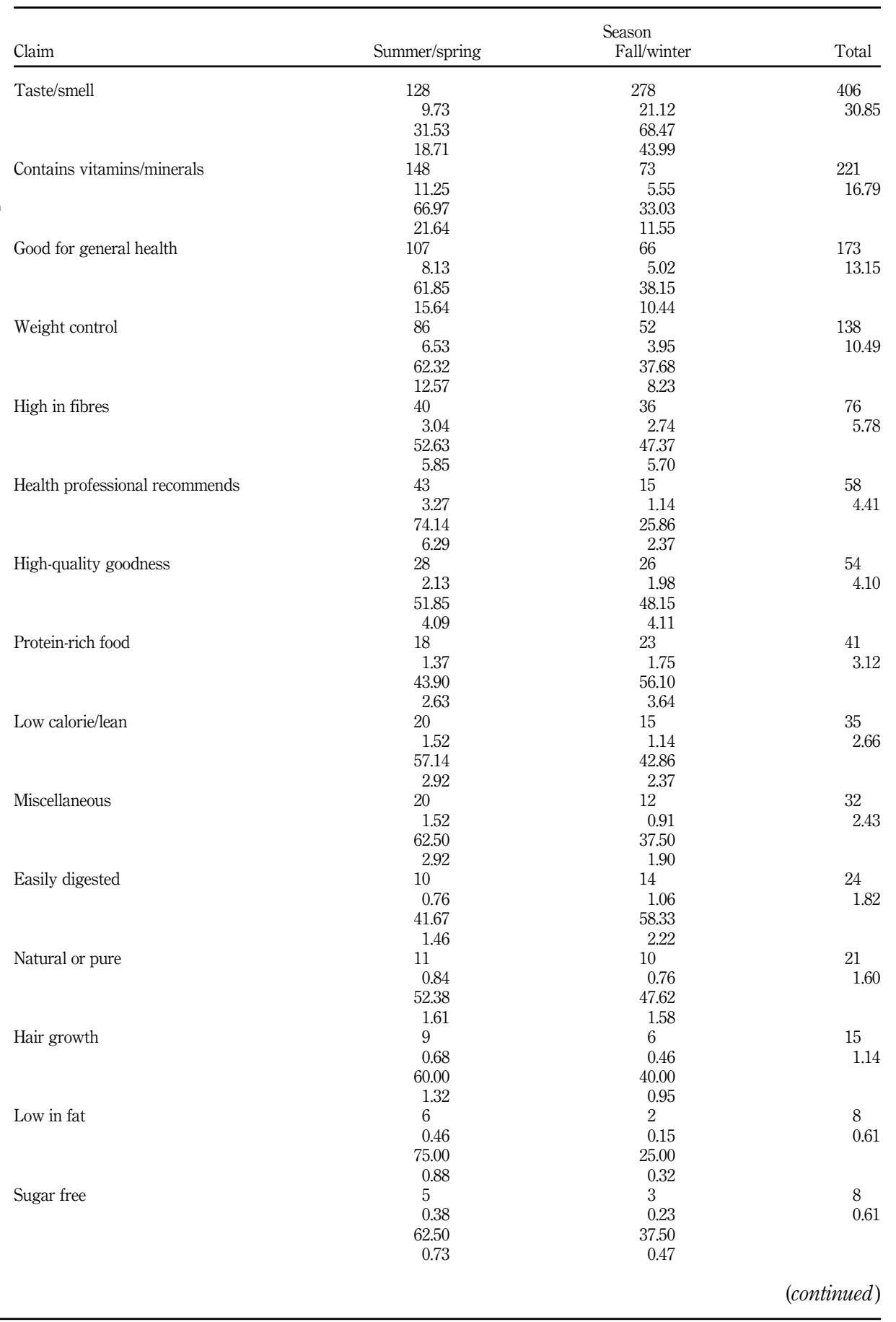

Table 11.

Claim per season 


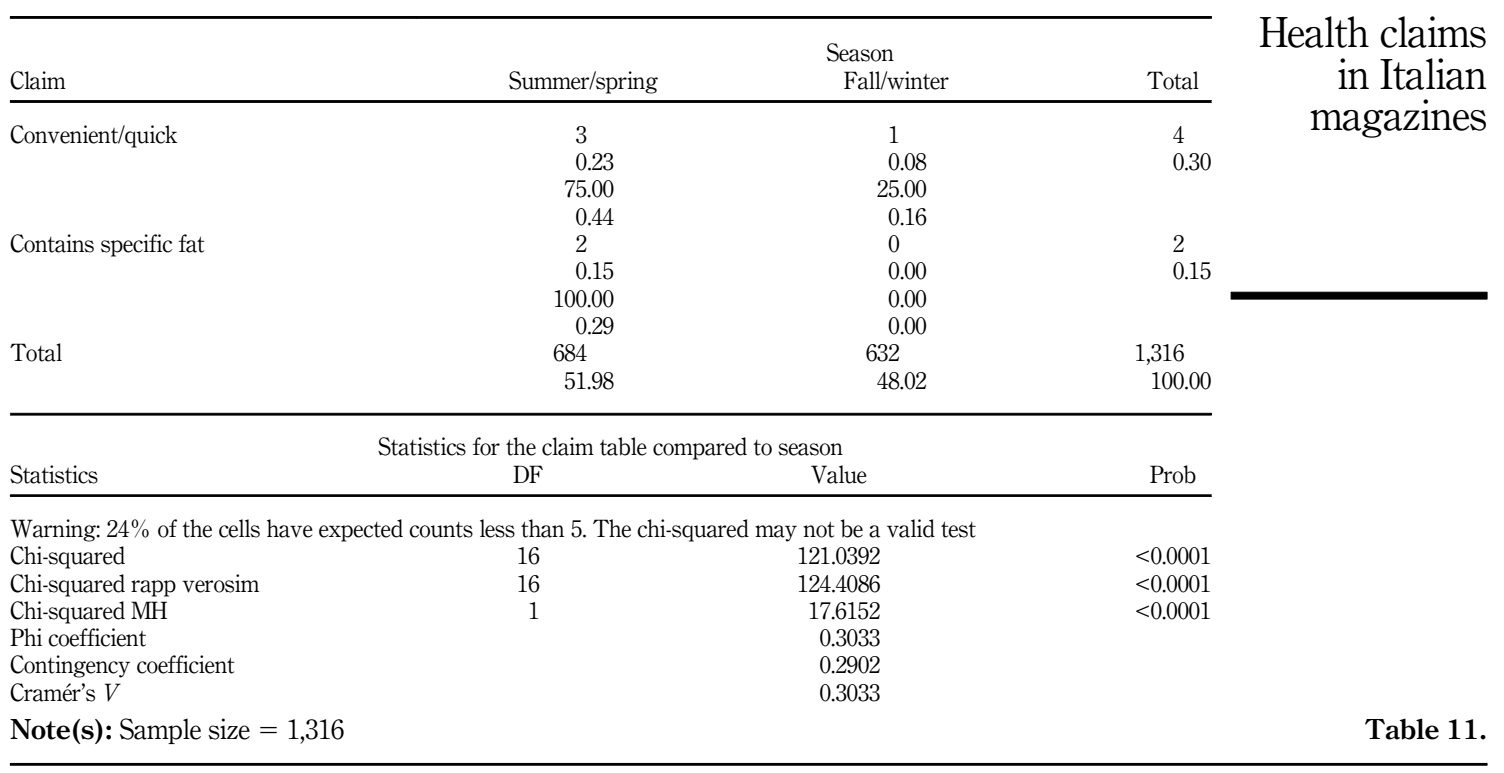

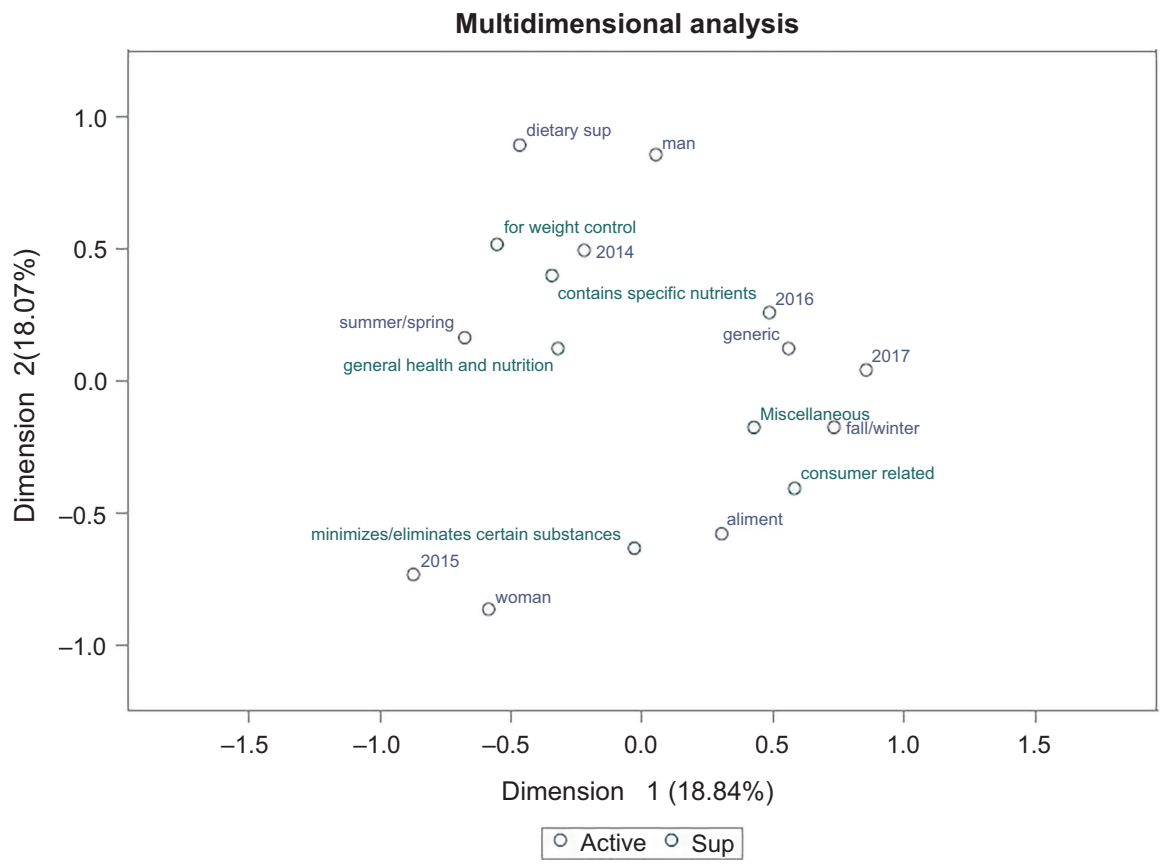

Figure 1. Multidimensional analysis

thoughtful design of promotional messages addressed to consumers so as to foster more reasonable choices. The authors intend to continue the analysis of print advertising messages, although they are aware that, while still being an important tool, magazines are 
losing their relevance as sources of information. The research could be extended by means of a similar study dedicated to television and social media, which are now more representative of food-related communication.

\section{References}

Abbatangelo-Gray, J., Byrd-Bredbenner, C. and Austin, S.B. (2008), "Health and nutrient content claims in food advertisements on hispanic and mainstream prime-time television", Journal of Nutrition Education and Behavior, Vol. 40, pp. 348-354.

Abrahams, Z., Temple, N.J., Mchiza, Z.J. and Steyn, N.P. (2016), "A study of food advertising in magazines in South Africa", Journal of Hunger and Environmental Nutrition, Vol. 0, pp. 1-13, doi: 10.1080/19320248.2016.1227757.

Adams, J., Simpson, E. and White, M. (2011), "Variations in food and drink advertising in UK monthly women's magazines according to season, magazine type and socio-economic profile of readers: a descriptive study of publications over 12 months", BMC Public Health, Vol. 11, pp. 368-375.

Anastasiou, K., Miller, M. and Dickinson, K. (2019), “The relationship between food label use and dietary intake in adults: a systematic review", Appetite, Vol. 138, doi: 10.1016/j.appet.2019.03.025.

Barr, S.I. (1989), "Nutrition in food advertising: content analysis of a canadian women's magazine, 1928-1986", Journal of Nutrition Education, Vol. 21 No. 2, pp. 64-72.

Burkitt, L. (2012), "Wal-mart to work harder on growth in China", available at: https://www.wsj.com/ articles/SB10001424052702304356604577340912309012378 (accessed 20 March 2019).

Byrd-Bredbenner, C. and Grasso, D. (2001), "Effect of the nutrition labeling education act (NLEA) on nutrient content claims and health claims in television advertising", Family Economics and Nutrition Review, Vol. 13, pp. 37-49.

Campos, S., Doxey, J. and Hammond, D. (2011), "Nutrition labels on pre-packaged foods: a systematic review", Public Health Nutrition, Vol. 14, pp. 1496-506.

Cecchini, M. and Warin, L. (2016), "Impact of food labelling systems on food choices and eating behaviours: a systematic review and meta-analysis of randomized studies", Obesity Reviews, Vol. 17 No. 3, pp. 201-210.

Celemín, L. and Jung, A. (2006), "What should be the role of the media in nutrition communication?", British Journal of Nutrition, Vol. 96 No. Suppl 1, pp. S86-S88, doi: 10.1079/BJN20061707.

Cervellon, M.C. and Laurette, D. (2000), "Standardization versus cultural adaptation in food advertising: insights from a two-culture market", International Journal of Advertising, Vol. 19 No. 4, pp. 429-447.

Chandon, P. and Wansink, B. (2012), "Does food marketing need to make us fat? A review and solutions", Nutrition Reviews, Vol. 70, pp. 571-593.

Cheong, Y., Kim, K. and Zheng, L. (2010), "Advertising appeals as a reflection of culture: a crosscultural analysis of food advertising appeals in China and the US", Asian Journal of Communication, Vol. 20 No. 1, pp. 1-16.

Cho, Y., Johnson, T. and Fendrich, M. (2001), "Monthly variations in self-reports of alcohol consumption”, Journal of Studies on Alcohol, Vol. 62, pp. 268-272.

Fay, M. (2003), "A 50-year longitudinal study of changes in the content and form of food advertising in New Zealand magazines", International Journal of Advertising, Vol. 22, pp. 67-91.

Gough, D. (2007), "Weight of evidence: a framework for the appraisal of the quality and relevance of evidence", Research Papers in Education, Vol. 22, pp. 213-228.

Greenacre, M.J. (1994), "Multiple and joint correspondence analysis", in Greenacre, M.J. and Blasius, J. (Eds), Correspondence Analysis in the Social Sciences, Academic Press, London.

Hayes, A.F. and Krippendorff, K. (2007), "Answering the call for a standard reliability measure for coding data", Communication Methods and Measures, Vol. 1, pp. 77-89. 
Ippolito, P.M. and Pappalardo, J.K. (2002), Advertising Nutrition and Health: Evidence from Food Advertising 1977-1997, Bureau of Economics Staff Report, Federal Trade Commission, Washington, District Columbia.

Kearney, J. (2010), "Food consumption trends and drivers", Philosophical Transactions of the Royal Society B, Vol. 365, pp. 2793-2807.

Kerr, M.A., McCann, M.T. and Livingstone, M.B. (2015), "Food and the consumer: could labelling be the answer?", Proceedings of the Nutrition Society, Vol. 74, pp. 158-163.

Kim, K., Cheong, Y. and Zheng, L. (2009), "The current practices in food advertising”, International Journal of Advertising, Vol. 28 No. 3, pp. 527-553.

Kozup, J.C., Creyer, E.H. and Burton, S. (2003), "Making healthful food choices: the influence of health claims and nutrition information on consumers' evaluations of packaged food products and restaurant menu items", Journal of Marketing, April 2003, Vol. 67, No. 5, pp. 19-34.

Lebart, L., Morineau, A. and Warwick, K.M. (1984), Multivariate Descriptive Statistical Analysis: Correspondence Analysis and Related Techniques for Large Matrices, John Wiley and Sons, New York.

Livingstone, S. and Helsper, E. (2004), "Advertising 'unhealthy' foods to children: understanding promotion in the context of children's daily lives", in A Review of the Literature for the Market Research Department of the Office of Communications (OFCOM), OFCOM, London.

Lohmann, J. and Kant, A.K. (2000), "Comparison of food groups and health claims appearing in food advertisements in 3 popular magazine categories", Journal of the American Medical Association, Vol. 100, pp. 1396-1399.

Massè, M.A. and Rosenblum, K. (1988), "Male and female created them: the depiction of gender in the advertising of traditional women's and men's magazines", Women's Studies International Forum, Vol. 11 No. 2, pp. 127-144.

Nielsen (2018), “Il Mercato Pubblicitario In Italia nel 2017”, available at: https://www.primaonline.it/ wp-content/uploads/2018/02/Nielsen_20180215_nota_adv_dicembre_def.pdf (accessed 19 march 2019).

Nocella, G. and Kennedy, O. (2012), "Food health claims-what consumers understand", Food Policy, Vol. 37 No. 5, pp. 571-580, doi: 10.1016/j.foodpol.2012.06.001.

O'Dowd, A. (2017), "Spending on junk food advertising is nearly 30 times what government spends on promoting healthy eating", BMJ, Vol. 359, p. j4677.

Parker, B.J. (2003), "Food for health: the use of nutrient content, health and structure/function claims in food advertisement", Journal of Advertising, Vol. 32, pp. 47-55.

Popkin, B.M. (2006), "Global nutrition dynamics: the world is shifting rapidly toward a diet linked with noncommunicable diseases", American Journal of Clinical Nutrition, Vol. 84, pp. 289-298.

Pratt, C.A. and Pratt, C.B. (1995), "Comparative content analysis of food and nutrition advertisements in ebony, essence and ladies", Journal of Nutrition Education, Vol. 27, pp. 11-17.

Roe, B., Alan, S.L. and Brenda, M.D. (1999), "The impact of health claims on consumer search and product evaluation outcomes: results from FDA experimental data", Journal of Public Policy and Marketing, Vol. 18, p. 89.

Silverstein, B., Perdue, L. and PetersonKelly, B.E. (1986), "The role of the mass media in promoting a thin standard of bodily attractiveness for women", Sex Roles, Vol. 14, pp. 519-532.

Spencer, R.J., Russell, J.M. and Barker, M.E. (2013), “Temporality in British young women's magazines: food, cooking and weight loss", Public Health Nutrition, Vol. 17, pp. 2359-2367.

Statista (2019), "Food advertising in the United States", in Statista Dossier on Food Advertising in the U.S., Hamburg.

Van Trijp, H.C.M. and Van der Lans, I.A. (2007), "Consumer perceptions of nutrition and health claims", Appetite, Vol. 48, pp. 305-324.
Health claims in Italian magazines 
Wansink, B. (2003), "Using laddering to understand and leverage a brand's equity", Qualitative Market Research: An International Journal, Vol. 6 No. 2, pp. 111-118.

Warner, K.E. (2006), "Tobacco policy research: insights and contributions to public health policy”, in Warner, K.E. (Ed.), Tobacco Control Policy, Jossey-Bass, San Francisco, pp. 3-86.

Wognum, N. and Bremmers, H. (2009), "Environmental transparency of food supply chains - current status and challenges global perspective for competitive enterprise", Economy and Ecology, pp. 645-652.

Xiaoli, N., Rowena, B., Hongmei, S., Hua, J. and Ai, Z. (2013), "A current appraisal of health- and nutrition-related claims in magazine food advertisements", Journal of Health Communication: International Perspectives, Vol. 18 No. 3, pp. 263-277.

Yale Rudd Center (2014), "Food marketing FACTS in Focus: kraft lunchables", Yale Rudd Report for Food Policy and Obesity, April 2014, pp. 1-36.

\section{Corresponding author}

Andrea Apicella can be contacted at: andapice@gmail.com

For instructions on how to order reprints of this article, please visit our website: 